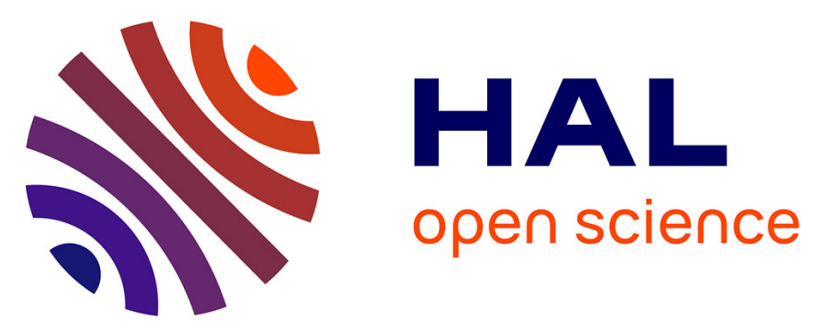

\title{
Endangered by laws: potential consequences of regulations against thistles on bumblebee conservation
}

Sarah Vray, Thomas Lecocq, Stuart P.M. Roberts, Pierre Rasmont

\section{To cite this version:}

Sarah Vray, Thomas Lecocq, Stuart P.M. Roberts, Pierre Rasmont. Endangered by laws: potential consequences of regulations against thistles on bumblebee conservation. Annales de la Société Entomologique de France, 2017, 53 (1), pp.33-41. 10.1080/00379271.2017.1304831 . hal-01972531

\section{HAL Id: hal-01972531 \\ https://hal.univ-lorraine.fr/hal-01972531}

Submitted on 4 Dec 2020

HAL is a multi-disciplinary open access archive for the deposit and dissemination of scientific research documents, whether they are published or not. The documents may come from teaching and research institutions in France or abroad, or from public or private research centers.
L'archive ouverte pluridisciplinaire HAL, est destinée au dépôt et à la diffusion de documents scientifiques de niveau recherche, publiés ou non, émanant des établissements d'enseignement et de recherche français ou étrangers, des laboratoires publics ou privés. 


\section{Endangered by laws: potential consequences of regulations against thistles}

\section{2 on bumblebee conservation}

3 Sarah Vray ${ }^{1,2 *}$, Thomas Lecocq ${ }^{1,3}$, Stuart P.M. Roberts ${ }^{4}$, Pierre Rasmont ${ }^{1}$

$4{ }^{1}$ Laboratory of Zoology, Research institute of Biosciences, University of Mons, Place du Parc

5 20,B-7000, Mons, Belgium.E-mail: sarah.vray@umons.ac.be,

$6 \quad$ thomas.lecocq@umons.ac.be,pierre.rasmont@umons.ac.be.Phone: 0032.(0)65.37.34.35.

$7{ }^{2}$ Department of Geography, University of Namur, Rue de Bruxelles 61, B-5000 Namur,

$8 \quad$ Belgium. E-mail: sarah.vray@unamur.ac.be.

$9{ }^{3}$ Research Unit Animal and Functionalities of Animal Products (URAFPA), University of Lorraine - INRA, 2 Avenue de la Forêt de Haye, BP 172, F-54505, Vandoeuvre-lès-Nancy, France.E-mail: thomas.lecocq@univ-lorraine.fr

${ }^{4}$ Visiting Research Fellow, Reading University, Reading, RG6 6AR, UK

*Corresponding author. E-mail: sarah.vray@umons.ac.be or sarah.vray@gmail.com. Tel:

Running title: Regulations against thistles and bumblebee conservation.

Word count:

- Summary: 187 words

- Résumé : 220 words

- Main text: 2556 words

- Acknowledgements: 171 words

- References: 1069 words

- Table legend: 57 words

- Figure legends: 419 words

Number of tables: 2

Number of figures: 5

Number of references: 40 


\section{Summary}

Many Bumblebee (Bombus) species are undergoing a strong decline in Europe due to, amongst other things, a decrease of food resources. While leguminous plants (Fabaceae) are considered to be one of the main pollen sources of bumblebees, thistles (Asteraceae tribe Cardueae) have been suggested to be important for male diet. Yet, several European countries apply strict regulations against thistles since they are considered to be one of the principal weeds in agricultural landscapes. Such regulations could impact bumblebee conservation through disruption of male diet and ecology. Here, we assess the male-depending importance of thistles for bumblebee species based on field observations across countries where a legal regulation against thistles is in effect. We ultimately aim to evaluate the potential consequences of these regulations on bumblebee conservation. Our results confirm that most of floral visit observations of males occur on thistles (mainly Cirsium spp. and Carduus spp.) and some species are almost exclusively observed on them. Thistle removal is thus most likely a threat for bumblebees. Therefore, we advocate repealing the thistle removal acts to make way for alternative thistle regulations which reconcile biodiversity conservation and agricultural requirements.

\section{Résumé. Menacé par des lois : les conséquences potentielles des législations} d'échardonnage sur la conservation des bourdons.

Les bourdons sont en régression en Europe, en partie à cause d'une diminution de leurs ressources alimentaires. Alors que les légumineuses sont considérées comme étant une des principales sources de pollen pour les bourdons, les chardons (Asteraceae, tribu des Cardueae) ont été suggérés comme étant importants pour l'alimentation des mâles. Pourtant, plusieurs pays européens appliquent des règles législatives strictes contre les chardons car ils sont considérés comme étant des «mauvaises herbes » majeures dans le paysage agricole. De 
53 telles régulations pourraient avoir un impact sur la conservation des bourdons à travers la

54 perturbation de l'alimentation et de l'écologie des mâles. Ici, nous estimons l'importance des

55 chardons pour les mâles d'espèces de bourdons en se basant sur des observations sur le terrain

56 dans les différents pays où un règlement d'échardonnage est en vigueur. Notre objectif est

57 d'évaluer les conséquences potentielles de ces règlements sur la conservation des bourdons.

58 Nos résultats confirment que la plupart des visites florales des mâles sont observées sur les

59 chardons (principalement Cirsium spp. et Carduus spp.) et que certaines espèces sont presque

60 exclusivement observées sur ces plantes. La suppression des chardons constitue donc très

61 probablement une menace pour les bourdons. Par conséquent, nous préconisons d'abroger les

62 lois d'échardonnage pour faire place à des réglementations alternatives qui concilient la

63 conservation de la biodiversité et les besoins agricoles.

64 Keywords: Bombus, Cardueae, Carduus, Cirsium, floral resources, pollinator conservation, 65 weed control legislation. 


\section{Introduction}

Almost 90 percent of all flowering plant species are pollinated by animals (Ollerton et al. 2011). In cold and temperate regions of the Northern Hemisphere, the social species group of bumblebees (Bombus spp.) is the main pollinating agent (Heinrich 1979). However, many species are experiencing a strong population decline and range contraction fostered by landscape modifications and fragmentation, intensive use of agrochemicals, pathogen infections, competition with alien species, climate change, reduction in floral resources, and interactions between all these factors (Goulson et al. 2005). Conservation actions have been developed to ensure bumblebee survival and to avoid a major disruption of pollination service. One strategy aims to mitigate the current qualitative and quantitative reduction in floral resources (e.g. Carvell et al. 2007; Kleijn \& Raemakers 2008; Scheper et al. 2014) because bumblebees require a long term flowering and a large diversity in plant species (Persson \& Smith 2013; Rundlöf et al. 2014). Determining the most important plants for bumblebee diet and ecology is therefore essential to plan efficient conservation management.

Several studies based on field observations have pointed out that leguminous plants (Fabaceae) are among the main pollen sources for bumblebees, especially for scarcer species (Rasmont \& Mersch 1988; Goulson et al. 2005, 2008). However, most of these assessments consider only the worker caste. Since workers are often the most abundant caste during field studies, floral preferences of other castes could be blurred. Yet, other caste requirements are thought to be different (Goulson 2010). For instance, some studies have suggested the importance of thistles (Asteraceae tribe Cardueae; Tree of Life Web Project 2009) for male diet at regional scales (e.g. Croxton et al. 2002; Pywell et al. 2005; Carvell et al. 2006). Yet, several European countries apply strict legal regulations against thistles, aimed at curbing flowering, development and seed dispersal since they are considered to be noxious weeds in the agricultural landscape (Table 1). Under the assumption of the importance of thistles for 
bumblebees, such regulations could impact bumblebee conservation through disruption of male diet and ecology.

Here, we assess the importance of thistles for bumblebee males across countries with regulations against thistles by using field observations. We ultimately aim to evaluate the potential consequences of regulations against thistles on bumblebee conservation.

\section{Methods}

\section{Plant systematics and definition of "Thistles"}

We defined thistles as all species included in Cardueae (synonym: Cynareae); a monophyletic worldwide tribe in the Asteraceae family. It contains 2400 species and 73 genera (Barres et al. 2013). For historic reasons, we followed the broad interpretation of Scrophulariaceae s.l. as used in Flora Europaea Vol. 3 (Tutin et al. 1972).

\section{Database and description of the dataset}

We used opportunistic data consisting of 88974 field observations of bumblebee (only observations of individuals feeding on flowers) which are recorded in the database Banque de Données Fauniques de Gembloux et Mons (Rasmont \& Iserbyt 2013, Rasmont et al. 2015). For each observation we looked at, (i) the plant species visited, (ii) the location, (iii) the date, and (iv) the visiting bumblebee species. All observations were performed in countries with a regulation against thistles (Table 1), with a proportion of $61 \%$ in France, $28 \%$ in Belgium, $11 \%$ in UK and $0.05 \%$ in the Netherlands. Observations were not fully distributed evenly across countries but were gathered in several regions (see the spatial distribution map in Fig. 1, created using ArcGIS 10 Esri software). Observations were carried out from 1878 to 2015 and more than three-quarters (78\%) were in summer (11\% in June, $49 \%$ in July, and $18 \%$ in August). 
We assessed the importance of thistles at Bombus generic and specific levels.

At the generic level, we compared for each caste the number of observations on flower at three plant taxonomic levels: between (i) plant families ( $\mathrm{n}=88974$ observations), (ii) Asteraceae tribes ( $\mathrm{n}=15746$ observations) and (iii) Cardueae genera ( $\mathrm{n}=14110$ observations). Visit preferences between castes to different plant families were characterised using Correspondence Analysis (CA; 'FactoMineR' package) on the contingency table [34 plant families x 3 castes], only considering the plant families for which we had at least 50 observations (all castes combined). Moreover, since our data did not follow a normal distribution (Shapiro-Wilk test), differences in floral preferences between plant taxonomic groups were examined with nonparametric tests (two-sample Wilcoxon sign-rank tests) for each caste. All statistical analysis were done using R version 3.3.1 (R Development Core Team 2016).

At the Bombus species level (20 567 queen observations, 15007 male observations and 38 892 worker observations), we compared for each caste the relative number of observations on the Cardueae tribe.

Thereafter, we assessed more specifically the consequences of national regulations against thistles by comparing the number of individuals from each Bombus species feeding on the

132 four thistle species concerned by national regulations ( $\mathrm{n}=3016$ observations): Carduus

133 crispus L., Cirsium arvense (L.) (Fig. 2a) Scop., Cirsium palustre (L.) Scop. (Fig. 2b), and Cirsium vulgare (Savi) Ten (Tab. 1).

\section{Results}


Our CA showed differences in floral visit preferences between castes (Fig. 3). The total inertia contained in the contingency table [34 plant families x 3 castes] was fully retained in two dimensions (respectively $79.93 \%$ for Axis 1 and $20.07 \%$ for Axis 2). The first dimension (Axis 1) was mainly defined by three plant families: Solanaceae (39.79\%), Asteraceae (16.89\%), and Brassicaceae (15.48\%), and by two castes: queens (68.45\%) and males (21.98\%). The second dimension (Axis 2) was mainly explained by Fabaceae (28.59\%), Asteraceae $(26.81 \%)$ and Scrophulariaceae $(11.36 \%)$, and for the castes by males $(57.86 \%)$ and workers $(38.14 \%)$. The global pattern presented by the CA showed that, among the five most visited plant families, Asteraceae was highly associated with male observations (Fig. 3). Focus on percentages of observations (Fig. 4a) and Wilcoxon sign-rank tests confirmed that males were significantly more observed on Asteraceae than on other families ( $41 \%$ of the 15007 male observations; Wilcoxon sign-rank test, $\mathrm{W}=1324400$, $\mathrm{p}$-value < 0.01). Queens $19 \%$ and $14 \%$ of the 20567 queen observations; only $7 \%$ on Asteraceae) and workers on Fabaceae, Asteraceae and Lamiaceae families (respectively 22\%, 19\% and 14\% of the 38892 worker observations). The surprisingly high percentage of queens recorded on Solanaceae is explained by observations of Bombus terrestris queens on Salpichroa origanifolia (Lam.) Baill. during September and October (4082 of the 4123 queens observations on Solanaceae). Among observations on Asteraceae, the Cardueae tribe was significantly more visited than other tribes by males (90\% of the 5947 males observations, Wilcoxon sign-rank test, $\mathrm{W}=$ 84052, p-value $<0.001)$ and by workers ( $92 \%$ of the 7413 workers observations, Wilcoxon sign-rank test, $\mathrm{W}=70105$, p-value $<0.001$ ), and recorded $79 \%$ of the 1446 queens (Fig. $4 \mathrm{~b}$ ). Among observations on Cardueae, 61\% of the 1112 queens were observed on Cirsium spp., $22 \%$ on Centaurea spp. and 13\% on Carduus spp. The 4722 male observations and the 6738 
worker observations were quite equitably distributed among the three genera (respectively $36 \%$ and $35 \%$ for Carduus, $30 \%$ and $32 \%$ for Centaurea, and $29 \%$ both for Cirsium; Fig. 4c).

\section{Bumblebee species most observed on thistles}

Regarding the bumblebee specific richness, a total of 43 species was recorded on Cardueae (of the 45 species, all plant species included). For several species, more than half of recorded visits were to this tribe. (Table 2, Fig. 5a). The largest numbers, in descending order were: Bombus veteranus (95\% of the observations), B. quadricolor (61\%), B. mucidus (59\%), B. mesomelas (56\%) and B. norvegicus (52\%; Fig. 5a).

Moreover, comparative analyses between castes show that many species have one or two castes which are very often observed on Cardueae. Bombus veteranus males and workers were almost exclusively recorded on this tribe (respectively $98 \%$ and $96 \%$ of the observations). Males of B. mucidus (87\%), B. mesomelas (86\%), B. confusus (85\%), B. mendax (81\%), B. lapidarius (73\%), B. quadricolor (70\%) and B. sylvarum (70\%) were also commonly seen on Cardueae (Fig. 5a).

\section{Importance of the four thistle species included in the regulations}

36 bumblebee species were observed on the four Cardueae species included in the regulations (see Table S1 in Supporting Information), with the two most visited being Cirsium palustre and $C$. vulgare. The most frequently observed bumblebee species on these four plants were $B$. norvegicus, B. distinguendus, B. campestris, B. quadricolor, B. soroeensis, B. bohemicus and B. sylvestris (respectively 19\%, 17\%, 16\%, 15\%, 12\%, 11\%, and 10\% of the observations; Fig. $5 b) .16 \%$ of all the B. norvegicus specimens, $13 \%$ of all the B. quadricolor specimens and $11 \%$ of all the B. soroeensis specimens were observed on the single species Cirsium 
palustre, while $14 \%$ of all the $B$. distinguendus specimens and $10 \%$ of all the $B$. campestris were observed on Cirsium vulgare.

\section{Discussion}

\section{Importance of thistles for bumblebee males}

We confirm at a larger geographic scale previous results (e.g. Carvell 2002; Carvell et al. 2006; Goulson et al. 2008) highlighting the large number of bumblebee male floral visits on Cardueae (mainly Carduus spp., Centaurea spp. and Cirsium spp). This strongly suggests an important role of Cardueae as a nectar resource during late summer when males perform their energy-consuming courtship behaviour (e.g. Croxton et al. 2002; Pywell et al. 2005; Goulson 2010). The lower number of workers and queens foraging on Cardueae could be explained by their need to collect pollen in addition to nectar for the colony development, unlike males which only feed on nectar. Yet, Asteraceae pollen is rarely found in queens and workers pollen loads (Goulson 2010), probably because it may represent a non-optimal diet for bumblebee colonies. This has recently been shown with the relative unsuitability of Cirsium pollen for the colony development of B. terrestris (Vanderplanck et al. 2016). It would have been of great interest to perform a comparison between time-periods of the importance of thistles in the foraging choice of bumblebees. However, our data set does not allow us to perform such a detailed study, because of the very different sampling efforts along time.

Importance of Cardueae has also been pointed out for other insect pollinators (Vanbergen et al. 2014; Ricou et al. 2014). For instance, in the greenways and sown wildflower strips of Southern Sweden, Cirsium spp. and Centaurea spp. were the most visited plant species by eight bumblebee species, but also by 18 butterfly species (Haaland \& Gyllin 2009). Cardueae are especially important in areas with intensive agriculture, where pollinators in general have a narrower spectrum and abundance of flowering plants (e.g. Cirsium species are a major 
foraging source where other wildflower species are absent; Haaland \& Gyllin 2009). Beside flower visiting insects, many phytophagous species are associated with Cardueae (Freese 1994) while thistle seeds provide food resource for some beetles, birds and rodents (McCallum \& Kelly 1990).

\section{Potential consequences of regulations against thistles on bumblebee conservation}

The four thistle species concerned by regulations against thistles in Belgium, France, the Netherlands and UK (i.e. Carduus cripus, Cirsium arvense, Cirsium palustre and Cirsium vulgare, Table 1) are commonly visited by male bumblebees (Fig. $5 \mathrm{~b}$ and Table $\mathrm{S} 1$ in Supporting information). The regulations could thus (i) greatly reduce the availability of food resources for, especially, bumblebee males during mating period and (ii), consequently, decrease the offspring production reinforcing the bumblebee decline through the population size decrease and the "extinction vortex" (Gilpin \& Soulé 1986; Zayed \& Packer 2005). Such a phenomenon is most likely in "Threatened" or "Near Threatened" (Cederberg et al. 2013) species commonly visiting thistle flowers (e.g. B. confusus, B. distinguendus, B. mucidus, B. veteranus; Rasmont et al. 2015). Moreover, thistle removal acts may affect several other plant species. Indeed, the correct identification of the species that are legislated against is not always easy for farmers and landowners. For the general public, "thistle" refers to all flowering plants characterized by leaves with sharp prickles on the margins. This usually implies that all thistles and thistle-like plants are wiped out leading to other Cardueae species decline (e.g. in Belgium, Cirsium dissectum, Cirsium tuberosum, Carduus nutans and Cirsium eriophorum; Crémer et al. 2008). Furthermore, many measures taken to eradicate thistles (e.g. repeated mowing, fertilize and lime to ensure the maintenance of an herbaceous cover, or herbicides) also affect non-Cardueae plants (e.g. Turner et al. 2007; Crémer et al. 2008; Andreasen \& Andresen 2011), including Fabaceae, the main food resources for bumblebee females (Fig. 4a). 
Because of the importance of thistles for bumblebee males (and also for other species ensuring the pollination ecosystem service) there is a premium on repealing the thistle removal acts but also on limiting Cardueae suppression in regions where thistle removal is not mandatory but is still carried out by most farmers (Bond \& Grundy 2001; Turner et al. 2007; Melander et al. 2012). Moreover, bumblebees can act as umbrella species for the other organisms associated with thistle and thistle-like plants (butterflies, other bees and hoverflies).

Despite the obvious benefit of minimising the removal of Cardueae for many pollinators, agricultural policy requires the control of thistles in order to maintain farmland productivity. Indeed, some thistles may weaken pasture and crops due to their allelopathy (i.e. releasing soluble inhibitors that discourage the growth of pasture grasses and legumes; Wardle et al. 1993), their highly effective seed dispersal and their clonal spreading ability (leading to large area monopolization; Kelemen et al. 2014). In grasslands, thistle control can be achieved by prevention techniques that maintain a large floral diversity (e.g. avoiding over-fertilizing, over- or under-grazing, and bare soils) coupled with more specific methods (e.g. alternating mowing and grazing). In crops, thistle control without the use of pesticides is possible by using crop rotation and stubble techniques (Andreasen \& Andresen 2011; Nicholls \& Altieri 2013). When such actions in croplands and grasslands are not possible, maintaining tolerable densities of thistles in fields could help to support pollinator populations (Nicholls \& Altieri 2013). Moreover, thistle removal in other areas should not be promoted because they are very rarely a problem outside farmlands. Therefore, gardens can act as refuges for bees and bumblebees in urban environments and intensively managed farmlands, as already suggested by previous studies (e.g. Ahrné et al. 2009; Samnegård et al. 2011). 
In summary, thistle removal regulations are obsolete because they are based on an old agricultural context, and methods of weed control have evolved since their establishment (Andreasen \& Andresen 2011). These regulations should therefore be re-evaluated, taking into account the increasing consideration of biodiversity in agricultural landscapes (Nicholls \& Altieri 2013) and particularly the high priority given to the wild pollinator conservation (IPBES 2016).

\section{Acknowledgments}

This research was supported by the Belgian Science Policy (project BR/132/A1/BELBEES). We acknowledge the committee and members of BWARS (the UK Bees, Wasps and Ants Recording Society) for access to their data holdings for UK. We also thank the numerous recorders who contributed to gather field observations in the four countries, especially R.G. Adam, R. Barone, C.J. Booth, P. Castle, C. Claessens, K. Colsell, P. Coppens, J.E. Crossley, B. Dawson, T. De Meulemeester, E. De Tré, E. Delattre, I. Demeuldre, K. Duncan, A. Durant, G. Else, P. Entwistle, J.F. Godeau, E. Grant, J. Hlusek, S. Iserbyt, A. Lachaud, G. Mahé, M. McDonald, B. Neill, G. Nisbet, S. Patiny, A. Pauly, R. Paxton, O. Ponchau, P. Sagot, M. Terzo, and M. Vandenbergh. We also would like to thank all the persons that helped us collecting information about legislations against thistles across Western Europe: Y. J. Anagnostopoulos, D. Baldock, E. Budrys, I. Calabuig, L. Castro, M. Cornalba, M. Franzén, D. Goulson, R. Haveman, A. Jenic, D. Kleijn, M. Quaranta, H. P. Ravn, P. Sima, C. Vanappelghem, W. Vogt-Kaute, and P. Williams. We also thank J.-M. Michalowski for the use of his two photographs.

\section{References}

Ahrné K, Bengtsson J, Elmqvist T, Ahrne K. 2009. Bumble bees (Bombus spp) along a gradient of increasing urbanization. PLoS One [Internet] 4(5):e5574. Available from: 
http://dx.plos.org/10.1371/journal.pone.0005574

Andreasen C, Andresen LC. 2011. Managing farmland flora to promote biodiversity in Europe. CAB Reviews: Perspectives in Agriculture, Veterinary Science, Nutrition and Natural Resources. 6:1-11.

Barres L, Sanmartín I, Anderson CL, Susanna A, Buerki S, Galbany-Casals M, Vilatersana R. 2013. Reconstructing the evolution and biogeographic history of tribe Cardueae (Compositae). American Journal of Botany. 100:867-82.

Bond W, Grundy AC. 2001. Non-chemical weed management in organic farming systems. Weed Research. 41:383-405.

Carvell C. 2002. Habitat use and conservation of bumblebees (Bombus spp.) under different grassland management regimes. Biological Conservation. 103:33-49.

Carvell C, Meek WR, Pywell RF, Goulson D, Nowakowski M. 2007. Comparing the efficacy of agri-environment schemes to enhance bumble bee abundance and diversity on arable field margins. Journal of Applied Ecology. 44:29-40.

Carvell C, Roy DB, Smart SM, Pywell RF, Preston CD, Goulson D. 2006. Declines in forage availability for bumblebees at a national scale. Biological Conservation. 132:481-489.

Cederberg B, Michez D, Nieto A, Radchenko V, Rasmont P, Roberts S. 2013. Bombus. IUCN Red List of Threatened Species. Version 2013.2,1. [Internet]. Available from: www.iucnredlist.org

Crémer S, Knoden D, Stilmant D, Luxen P. 2008. Le contrôle des populations indésirables de rumex, chardons et orties dans les prairies permanentes. In: Delbeuck C, editor. Les Livrets de l'Agriculture. Vol. 17. Namur: Ministère de la Région Wallonne, Direction générale de l'Agriculture; p. 86.

Croxton PJ, Carvell C, Mountford JO, Sparks TH. 2002. A comparison of green lanes and 
field margins as bumblebee habitat in an arable landscape. Biological Conservation. 107:365-374.

Freese G. 1994. The insect complexes associated with the stems of seven thistle species. Entomologia generalis. 19:191-207.

Gilpin ME, Soulé ME. 1986. Minimum viable populations: processes of species extinction. In: Soulé ME, editor. Conservation biology: The Science of Scarcity and Diversity. Sunderland, MA: Sinauer Associates; p. 19-34.

Goulson D. 2010. Bumblebees: behaviour, ecology, and conservation. Oxford: Oxford University Press. $2^{\text {nd }}$ ed. 330pp.

Goulson D, Hanley ME, Darvill B, Ellis JS, Knight ME. 2005. Causes of rarity in bumblebees. Biological Conservation. 122:1-8.

Goulson D, Lye GC, Darvill B. 2008. Diet breadth, coexistence and rarity in bumblebees. Biodiversity and Conservation. 17:3269-3288.

Haaland C, Gyllin M. 2009. Butterflies and bumblebees in greenways and sown wildflower strips in southern Sweden. Journal of Insect Conservation 14:125-132.

Heinrich B. 1979. Bumblebee economics. Cambridge, London: Harvard University Press. 288pp.

IPBES (Intergovernmental Science-Policy Platform on Biodiversity and Ecosystem Services), Potts SG, Imperatriz-Fonseca VL, Ngo HT, Biesmeijer JC, Breeze DT, Dicks L V., Garibaldi LA, Hill R, Settele J, et al. 2016. Summary for policymakers of the assessment report of the Intergovernmental Science-Policy Platform on Biodiversity and Ecosystem Services on pollinators, pollination and food production. Secretariat of the Intergovernmental Science-Policy Platform on Biodiversity and Ecosystem Services. Bonn, Germany. 28pp. 
Kelemen A, Török P, Valkó O, Deák B, Miglécz T, Tóth K, Ölvedi T, Tóthmérész B. 2014. Sustaining recovered grasslands is not likely without proper management: vegetation changes after cessation of mowing. Biodiversity and Conservation. 23:741-751.

Kleijn D, Raemakers I. 2008. A retrospective analysis of pollen host plant use by stable and declining bumble bee species. Ecology. 89:1811-1823.

McCallum K, Kelly D. 1990. Pre- and post-dispersal predation of nodding thistle seeds by birds and rodents. In: Proceedings of the Forty-Third New Zealand Weed and Pest Control Conference. Proceedings; Pacific Park Hotel, Dunedin on 14-16 August 1990. pp. 216-219.

Melander B, Holst N, Rasmussen IA, Hansen PK. 2012. Direct control of perennial weeds between crops - Implications for organic farming. Crop Protection. 40:36-42.

Nicholls CI, Altieri MA. 2013. Plant biodiversity enhances bees and other insect pollinators in agroecosystems. A review. Agronomy for Sustainable Development. 33:257-274.

Ollerton J, Winfree R, Tarrant S. 2011. How many flowering plants are pollinated by animals? Oikos. 120:321-326.

Persson AS, Smith HG. 2013. Seasonal persistence of bumblebee populations is affected by landscape context. Agriculture, Ecosystems \& Environment. 165:201-209.

Pywell RF, Warman EA, Carvell C, Sparks TH, Dicks LV, Bennett D, Wright A, Critchley CNR, Sherwood A. 2005. Providing foraging resources for bumblebees in intensively farmed landscapes. Biological Conservation. 121:479-494.

R Development Core Team. 2016. R: A Language and Environment for Statistical Computing.Team RDC, editor. R Foundation for Statistical Computing, Vienna, Austria. Available from: http://www.r-project.org 
Project, Atlas Hymenoptera, Mons, Gembloux. Available from: http://www.zoologie.umh.ac.be//hymenoptera/page.asp?ID=169.

Rasmont P, Franzén M, Lecocq T, Harpke A, Roberts SPM, Biesmeijer JC, Castro L, Cederberg B, Dvorák L, Fitzpatrick Ú, et al. 2015. Climatic Risk and Distribution Atlas of European Bumblebees. Biorisk 10 (Special Issue):246pp.

Rasmont P, Mersch P. 1988. First estimation of faunistic drift by bumblebees of Belgium, (Hymenoptera: Apidae). Annales de la Societe Royale Zoologique de Belgique. 118:141147.

Ricou C, Schneller C, Amiaud B, Plantureux S, Bockstaller C. 2014. A vegetation-based indicator to assess the pollination value of field margin flora. Ecological Indicators. $45: 320-331$.

Rundlöf M, Persson AS, Smith HG, Bommarco R. 2014. Late-season mass-flowering red clover increases bumble bee queen and male densities. Biological Conservation. 172:138-145.

Samnegård U, Persson AS, Smith HG. 2011. Gardens benefit bees and enhance pollination in intensively managed farmland. Biological Conservation. 144:2602-2606.

Scheper J, Reemer M, van Kats R, Ozinga WA, van der Linden GTJ, Schaminée JHJ, Siepel H, Kleijn D. 2014. Museum specimens reveal loss of pollen host plants as key factor driving wild bee decline in The Netherlands. Proceedings of the National Academy of Sciences. 111: 17552-17557.

Tree of Life Web Project. 2009. Cardueae Cass.. Thistles. Version 11 January 2009. Tree Life Web Project [Internet]. Available from: http://tolweb.org/Cardueae/104543/2009.01.11

Turner RJ, Davies G, Moore H, Grundy AC, Mead A. 2007. Organic weed management: A review of the current UK farmer perspective. Crop Protection. 26:377-382. 
Tutin TG, Heywood VH, Burges NA, Moore DM, Valentine DH, Walters SM, Webb DA. 1972. Flora Europaea: Volume 3: Diapensiaceae to Myoporaceae. Cambridge: Cambridge University Press. 415pp.

Vanbergen AJ, Woodcock BA, Gray A, Grant F, Telford A, Lambdon P, Chapman DS, Pywell RF, Heard MS, Cavers S. 2014. Grazing alters insect visitation networks and plant mating systems. Functional Ecology. 28:178-189.

Vanderplanck M, Decleves S, Roger N, Decroo C, Caulier G, Glauser G, Gerbaux P, Lognay G, Richel A, Escaravage N, Michez D. 2016. Is non-host pollen suitable for generalist bumblebees? Insect Science [Internet]. Avalaible from: http://onlinelibrary.wiley.com/doi/10.1111/1744-7917.12410/full

Wardle DA, Nicholson KS, Rahman A. 1993. Influence of plant age on the allelopathic potential of nodding thistle (Carduus nutans L.) against pasture grasses and legumes. Weed Research. 33:69-78.

Zayed A, Packer L. 2005. Complementary sex determination substantially increases extinction proneness of haplodiploid populations. Proceedings of the National Academy of Sciences of the United States of America. 102:10742-6. 
Table 1. National regulations requiring the control of thistles in the European Union

\begin{tabular}{|c|c|c|c|}
\hline Countries & Period & Species concerned & Regulation's name / source \\
\hline Belgium & 1987 - present & $\begin{array}{l}\text { Carduus crispus } \\
\text { Cirsium arvense } \\
\text { Cirsium palustre } \\
\text { Cirsium vulgare }\end{array}$ & $\begin{array}{l}\text { "Arrêté royal du } 19 \text { novembre } 1987 \\
\text { relatif à la lutte contre les organismes } \\
\text { nuisibles aux végétaux et aux produits } \\
\text { végétaux." } \\
\text { (Crémer et al. 2008) }\end{array}$ \\
\hline France & 1994 - present & Cirsium arvense & $\begin{array}{l}\text { "Article L383 du Code Civil”; and } \\
\text { subsequent local legislations (i.e. } \\
\text { " arrêtés préfectoraux/municipaux”) }\end{array}$ \\
\hline $\begin{array}{l}\text { Netherlands (only } \\
\text { provinces Friesland, } \\
\text { Utrecht, Noord-Holland, } \\
\text { Zeeland, Zuid-Holland, } \\
\text { and Noord-Brabant) }\end{array}$ & 1950 - present & $\begin{array}{l}\text { Varies per province, } \\
\text { usually : } \\
\text { Cirsium arvense } \\
\text { Cirsium palustre } \\
\text { Cirsium vulgare }\end{array}$ & $\begin{array}{l}\text { Local legislations (i.e. } \\
\text { "Distelverordening } \\
\text { (bestrijdingsplicht)" and "Algemene } \\
\text { Plaatselijke Verordening (APV)") }\end{array}$ \\
\hline United Kingdom & 1959 - present & $\begin{array}{l}\text { Cirsium arvense } \\
\text { Cirsium vulgare }\end{array}$ & "Weeds Act 1959" \\
\hline
\end{tabular}


Table 2. Total number of specimens recorded on all plant species and number of specimens recorded on a plant species of the Cardueae tribe. $\mathrm{Q}=$ queen; $\mathrm{M}=$ male; $\mathrm{W}=$ worker; $\mathrm{U}=$ unknown. Bombus sp. are Bombus unspecified specimens in the database.

\begin{tabular}{|c|c|c|c|c|c|c|c|c|c|c|}
\hline \multirow[t]{2}{*}{ Bombus species } & \multicolumn{5}{|c|}{ Total number of specimens } & \multicolumn{5}{|c|}{$\begin{array}{c}\text { Number of specimens observed on a } \\
\text { Cardueae }\end{array}$} \\
\hline & $\mathrm{Q}$ & M & $\mathrm{W}$ & $\mathrm{U}$ & Total & $\mathrm{Q}$ & M & W & $\mathrm{U}$ & Total \\
\hline All Bombus species & 20567 & 15007 & 38892 & 14509 & 88974 & 1145 & 5334 & 6851 & 783 & 14113 \\
\hline Bombus sp. & 38 & 53 & 185 & 152 & 428 & 2 & 9 & 72 & 9 & 92 \\
\hline B. alpinus (L.) & 4 & 3 & 11 & 3 & 21 & - & - & - & - & - \\
\hline B. argillaceus (Scopoli) & 12 & 23 & 89 & 1 & 125 & - & 2 & 25 & - & 27 \\
\hline B. barbutellus (Kirby) & 26 & 118 & - & 2 & 146 & 4 & 25 & - & - & 29 \\
\hline B. bohemicus Seild & 249 & 1164 & - & 25 & 1438 & 20 & 546 & - & 8 & 574 \\
\hline B. brodmannicus Vogt & 36 & - & 29 & 2 & 67 & - & - & 1 & - & 1 \\
\hline B. campestris (Panzer) & 31 & 164 & - & 2 & 197 & 7 & 74 & - & - & 81 \\
\hline B. confusus Schenk & 21 & 81 & 92 & - & 194 & 3 & 69 & 18 & - & 90 \\
\hline B. cryptarum (Fabricius) & 528 & 98 & 235 & 1 & 862 & 2 & 56 & 16 & - & 74 \\
\hline B. cullumanus (Kirby) & 14 & 7 & 34 & - & 55 & 3 & 1 & 15 & - & 19 \\
\hline B. distinguendus Morawitz & 226 & 77 & 265 & 1564 & 2132 & 30 & 34 & 70 & 556 & 690 \\
\hline B. flavidus Eversmann & 5 & 122 & - & 1 & 128 & 4 & 45 & - & 1 & 50 \\
\hline B. gerstaeckeri Morawitz & 239 & 55 & 112 & 3 & 409 & - & - & - & - & - \\
\hline B. hortorum (L.) & 1051 & 661 & 1573 & 1357 & 4642 & 31 & 103 & 144 & 30 & 308 \\
\hline B. humilis Illiger & 306 & 148 & 1300 & 1 & 1755 & 10 & 77 & 263 & - & 350 \\
\hline B. hypnorum (L.) & 90 & 88 & 274 & 100 & 552 & 4 & 21 & 18 & 4 & 47 \\
\hline B. jonellus (Kirby) & 766 & 104 & 319 & 334 & 1523 & 16 & 16 & 13 & 2 & 47 \\
\hline B. lapidarius (L.) & 1056 & 1237 & 3204 & 477 & 5974 & 115 & 907 & 905 & 24 & 1951 \\
\hline B. lucorum (L.) & 1939 & 1722 & 3270 & 284 & 7215 & 31 & 219 & 215 & 17 & 482 \\
\hline B. magnus Vogt & 431 & 72 & 263 & 76 & 842 & 19 & - & 20 & 13 & 52 \\
\hline B. mendax Gerstaecker & 44 & 42 & 359 & 1 & 446 & 4 & 34 & 22 & - & 60 \\
\hline B. mesomelas Gerstaecker & 121 & 121 & 1058 & 17 & 1317 & 30 & 104 & 608 & 2 & 744 \\
\hline B. mocsaryi Kriechbaumer & 4 & - & 13 & - & 17 & 2 & - & 13 & - & 15 \\
\hline B. monticola Smith & 179 & 566 & 2357 & 213 & 3315 & 2 & 72 & 58 & - & 132 \\
\hline B. mucidus Gerstaecker & 33 & 47 & 182 & 2 & 264 & 3 & 41 & 113 & - & 157 \\
\hline B. muscorum (L.) & 204 & 81 & 239 & 70 & 594 & 27 & 44 & 101 & 20 & 192 \\
\hline B. norvegicus (Sparr & 2 & 73 & - & - & 75 & 1 & 38 & - & - & 39 \\
\hline B. pascuorum (Sc & 2695 & 984 & 4611 & 2343 & 10633 & 320 & 266 & 468 & 33 & 1087 \\
\hline B. perezi (Schu & 3 & 114 & - & - & 117 & - & 30 & - & - & 30 \\
\hline B. pereziellus (Skor & 19 & 6 & 32 & - & 57 & - & - & 1 & - & 1 \\
\hline B. pomorum (Panzer) & 41 & 16 & 119 & - & 176 & 12 & 8 & 56 & - & 76 \\
\hline B. pratorum (L.) & 886 & 718 & 1432 & 216 & 3252 & 7 & 105 & 131 & 17 & 260 \\
\hline B. pyrenaeus Pérez & 33 & 162 & 833 & 12 & 1040 & 4 & 82 & 114 & 1 & 201 \\
\hline B. quadricolor (Lepeletier) & 31 & 90 & - & 1 & 122 & 11 & 63 & - & - & 74 \\
\hline B. ruderarius (Müller) & 450 & 628 & 1608 & 24 & 2710 & 22 & 297 & 303 & 7 & 629 \\
\hline B. ruderatus (Fabricius) & 309 & 513 & 981 & 2 & 1805 & 4 & 36 & 33 & - & 73 \\
\hline B. rupestris (Fabricius) & 79 & 166 & - & 6 & 251 & 16 & 92 & - & 1 & 109 \\
\hline B. sichelii Radoszkowski & 40 & 75 & 940 & 14 & 1069 & 7 & 14 & 196 & 2 & 219 \\
\hline B. soroeensis (Fabricius) & 729 & 445 & 3671 & 65 & 4910 & 93 & 157 & 1321 & 4 & 1575 \\
\hline B. subterraneus (L.) & 94 & 155 & 385 & 1 & 635 & 4 & 60 & 50 & - & 114 \\
\hline B. sylvarum (L.) & 220 & 146 & 2400 & 20 & 2786 & 25 & 102 & 522 & 8 & 657 \\
\hline B. sylvestris (Lepeletier) & 118 & 306 & - & 27 & 451 & 15 & 140 & - & 4 & 159 \\
\hline B. terrestris (L.) & 6876 & 2447 & 4628 & 7052 & 21003 & 212 & 448 & 235 & 18 & 913 \\
\hline B. vestalis (Fourcroy) & 45 & 109 & - & 20 & 174 & 1 & 44 & - & 2 & 47 \\
\hline B. veteranus (Fabricius) & 69 & 848 & 705 & - & 1622 & 22 & 833 & 678 & - & 1533 \\
\hline B. wurflenii Radoszkowski & 175 & 151 & 1074 & 28 & 1428 & - & 20 & 32 & 1 & 53 \\
\hline
\end{tabular}


402

Figures

403

404 
405 Figure 1. Spatial distribution of the bumblebee observations feeding on flower in the four 406 countries concerned by thistles regulations (Belgium, France, The Netherlands, and UK). 


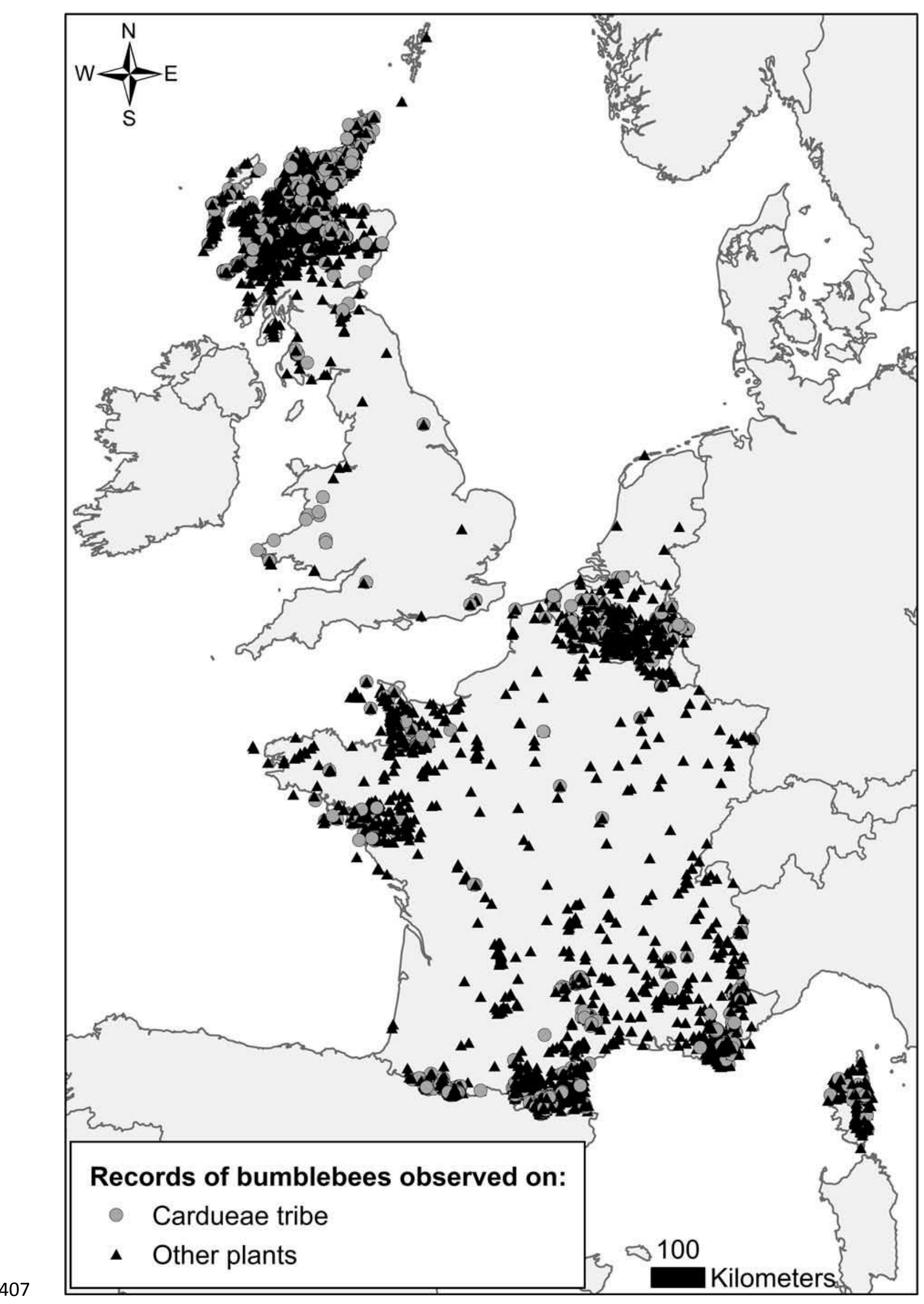


Figure 2. (a) Bombus rupestris male on Cirsium arvense, and (b) Bombus sylvestris male on 409 Cirsium palustre (Photos: J.-M. Michalowski).
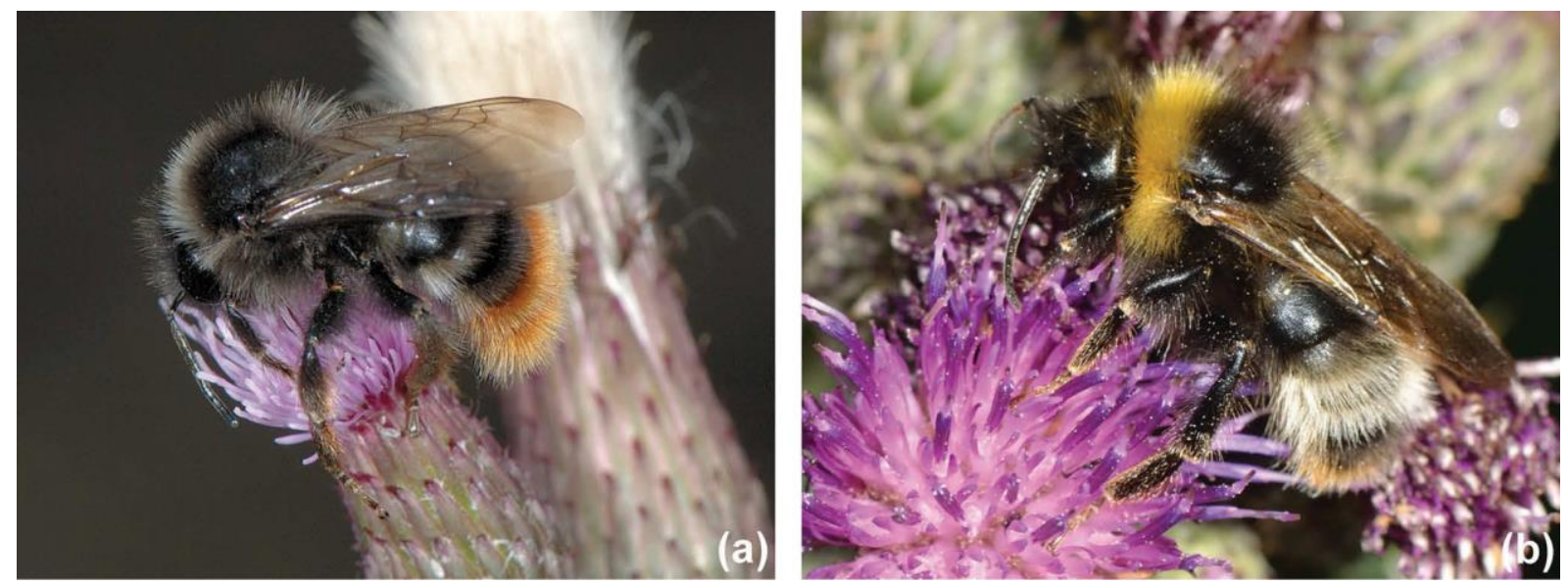

411 
Figure 3. Correspondence Analysis factor map obtained from the contingency table of the three 413 castes (triangles) and the 34 plant families for which we had more than 50 observations (points). Bigger points are the four plant families with more than 9000 observations, Asteraceae being the most visited family with 15015 observations. $M=$ males (14 874 obs.); $Q=$ queens (20 326 obs.); $\mathrm{W}=$ workers (38 579 obs.); Api = Apiaceae (1493 obs.); Bal = Balsaminaceae (52 obs.);

417 Ber = Berberidaceae (74 obs.); Bor = Boraginaceae (2642 obs.); Bra = Brassicaceae (2163 obs.);

418 Cam $=$ Campanulaceae $(747$ obs. $) ;$ Cap $=$ Caprifoliaceae $(74$ obs. $) ;$ Car $=$ Caryophyllaceae $(114$ obs. $)$; Cis $=$ Cistaceae $(184$ obs. $) ;$ Cra $=$ Crassulaceae $(113$ obs. $) ;$ Cuc $=$ Cucurbitaceae $(320$ obs.); Dip = Dipsacaceae (1223 obs.); Eri = Ericaceae (9570 obs.); Fab = Fabaceae (12 556

421 obs.); Gen = Gentianaceae (436 obs.); Ger = Geraniaceae (227 obs.); Gro = Grossulariaceae 422 (485 obs.); Gut = Guttiferae (176 obs.); Hyd = Hydrophyllaceae (443 obs. $)$; Lam = Lamiaceae 423 (9624 obs.); Lil = Liliaceae $(618$ obs. $) ;$ Lyt = Lythraceae $(142$ obs. $) ;$ Mal = Malvaceae $(121$ obs.); Ole = Oleaceae (64 obs.); Ona = Onagraceae (1533 obs.); Pap = Papaveraceae (149 obs.); Pol = Polygonaceae (52 obs.); Ran = Ranunculaceae (2430 obs.); Ros = Rosaceae (2386 obs.); Sal = Salicaceae (359 obs.); Scr = Scrophulariaceae (3434 obs.); Sol = Solanaceae (4643 obs.);

$427 \quad$ Til $=$ Tiliaceae $(117$ obs. $)$. 


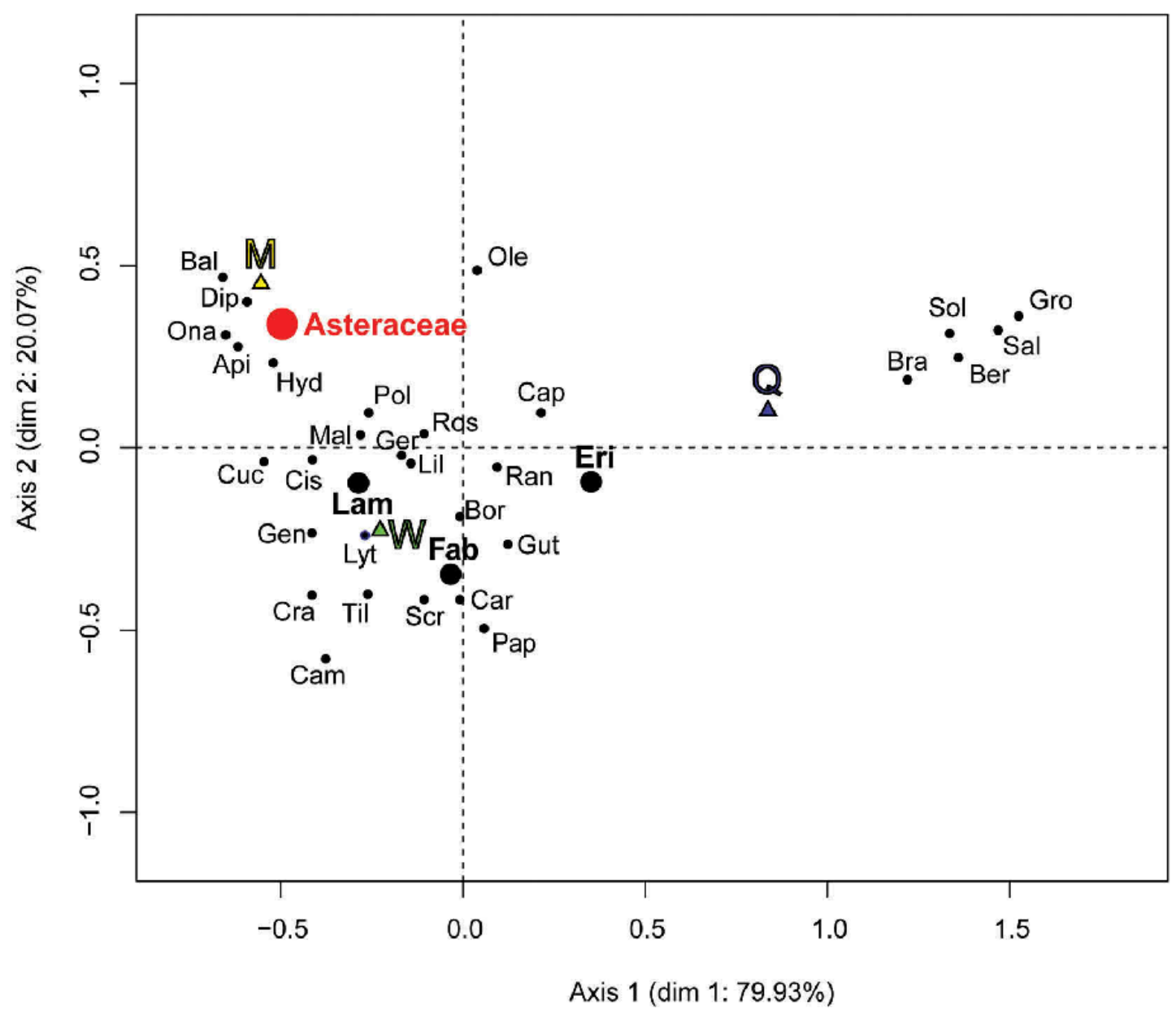

429 
Figure 4. Number of bumblebee specimens recorded to different (a) plant families (all 431 bumblebee species combined; $\mathrm{N}=88974$ specimens), (b) tribes of the Asteraceae family (all 432 bumblebee species combined; $\mathrm{N}=15746$ specimens), and (c) genera of the Cardueae tribe (all 433 bumblebee species combined; $\mathrm{N}=13353$ specimens). "Others" are (a) 79 plant families with 434 less than 800 observations each totalling 5912 observations, (b) 10 tribes of Asteraceae with 435 less than 70 observations each totalling 240 observations, and (c) 8 genera of Cardueae with 436 less than 40 observations each totalling 100 observations.

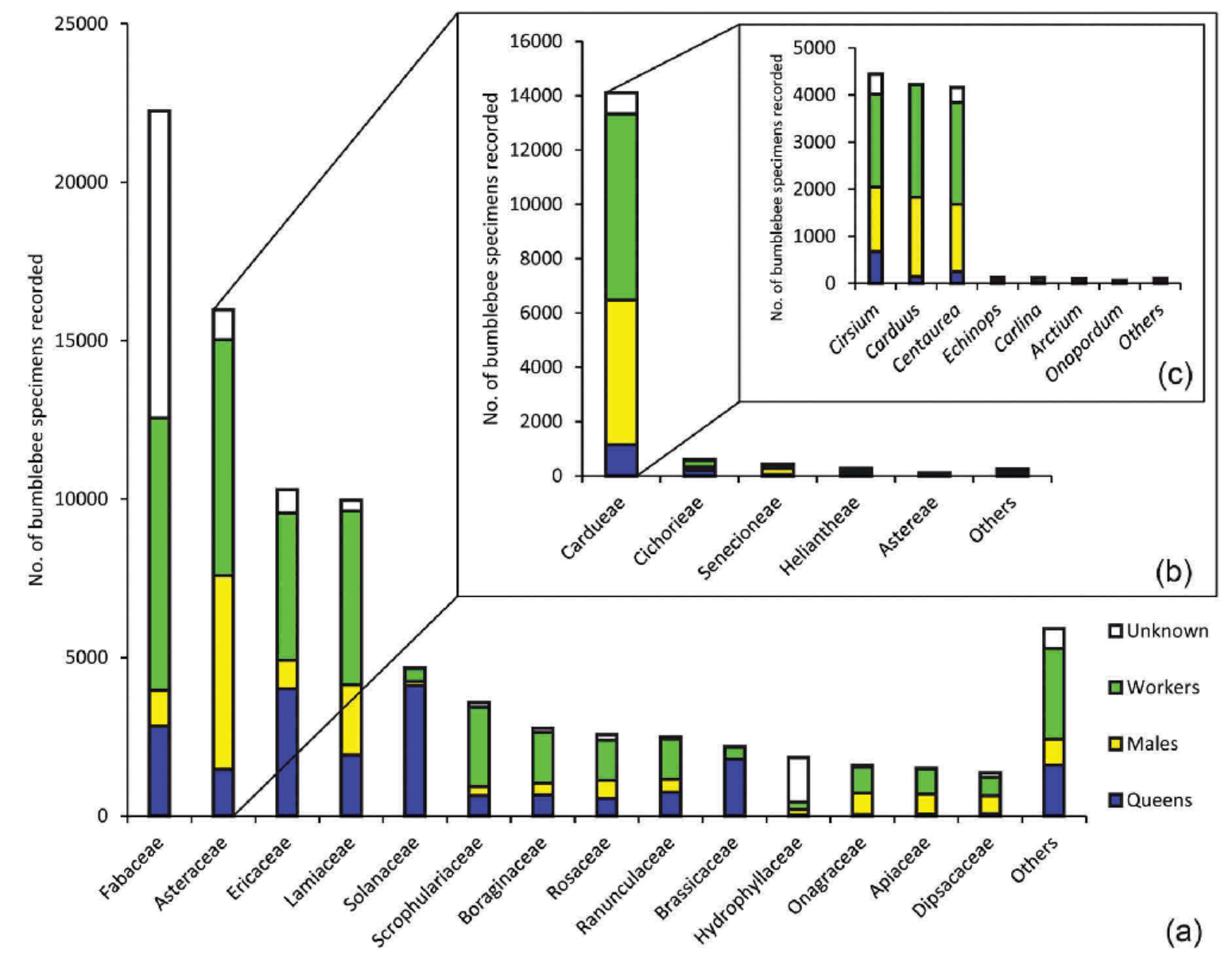


439 Figure 5. Proportion of bumblebee specimens observed on (a) Cardueae and (b) the four thistle

440 species concerned by the regulations (number on Cardueae $=14113$ specimens; number on the

441 four species $=3016$ specimens; total number $=88974$ specimens). Only species with a

442 percentage higher than (a) 25\% and (b) $3 \%$ (for all castes combined) are presented.

(a)

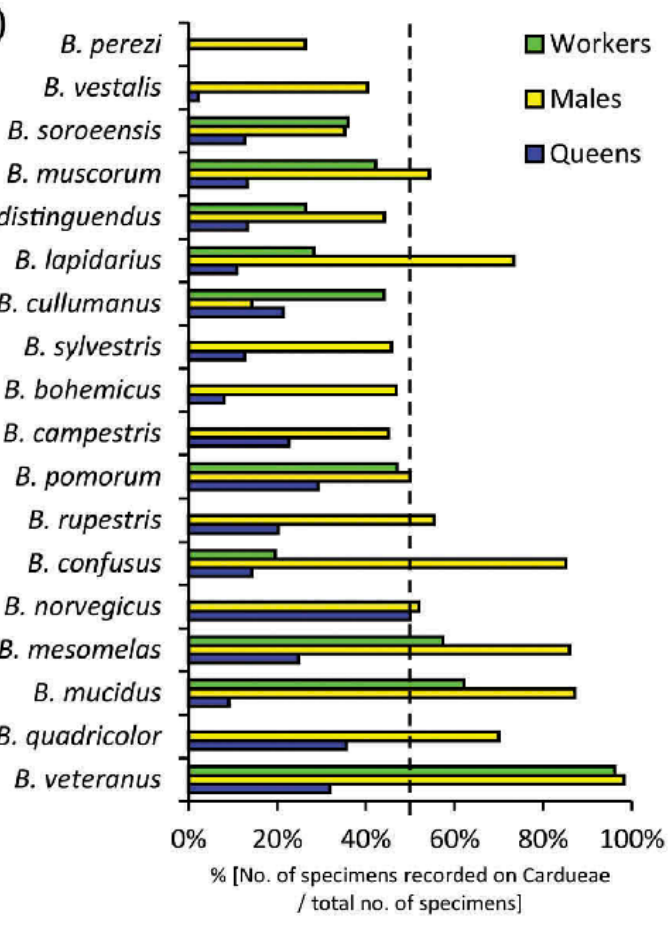

(b)

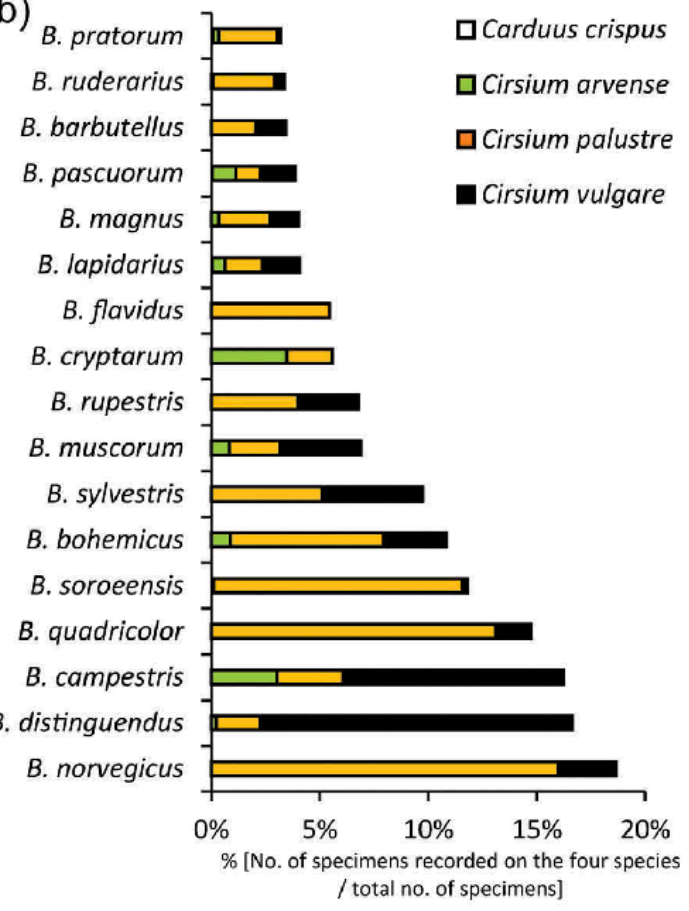

